\title{
Engineering characterisation of single-use bioreactor technology for mammalian cell culture applications
}

\author{
Akinlolu Odeleye*, Gary J Lye, Martina Micheletti \\ From 23rd European Society for Animal Cell Technology (ESACT) Meeting: Better Cells for Better Health \\ Lille, France. 23-26 June 2013
}

\section{Background}

The commercial success of mammalian cell-derived recombinant proteins has fostered an increase in demand for novel single-use bioreactor (SUB) systems, that facilitate greater productivity, increased flexibility and reduced costs. Whilst maintaining auspicious mixing parameters, these systems exhibit fluid flow regimes unlike those encountered in traditional glass/stainless steel bioreactors. With such disparate mixing environments between SUBs currently on the market, the traditional scale-up procedures applied to stirred tank reactors (STRs) are not adequate. The aim of this work is to conduct a fundamental investigation into the hydrodynamics of single-use bioreactors at laboratory scale to understand its impact upon the growth, metabolic activity and protein productivity of an antibody-producing mammalian cell culture.

\section{Materials and methods}

This work presents a study characterising the macromixing, fluid flow pattern, turbulent kinetic energy (TKE), energy dissipation rates (EDRs), and shear stresses within these bioreactor systems carried out using 2dimensional Particle Image Velocimetry (PIV). PIV enables acquisition of whole-field flow characteristics through instantaneous velocity measurements. The SUBs employed in the PIV measurements include the 3L CellReady (Merck Millipore), PBS Biotech's PBS 3 bioreactor and the Sartorius 2L BIOSTAT Cultibag RM.

The CellReady is a stirred tank bioreactor (3 litre volume), housing a 3-bladed upward-pumping marine scoping impeller. The PIV study was conducted using the actual vessel which has an internal diameter $\left(D_{T}\right)$ of

\footnotetext{
* Correspondence: akinlolu.odeleye.09@ucl.ac.uk

Department of Biochemical Engineering, University College London, London, WC1E 7JE, UK
}

\section{Results and discussion} Thenenders compartmentalisation of the fluid flow. This turn contributes to the wide range of turbulence levels conveyed between the lower quarter and upper three quarters of the fluid. The maximum fluid velocity of $0.25 \mathrm{U}_{\text {tip }}$ is achieved in the impeller discharge stream 


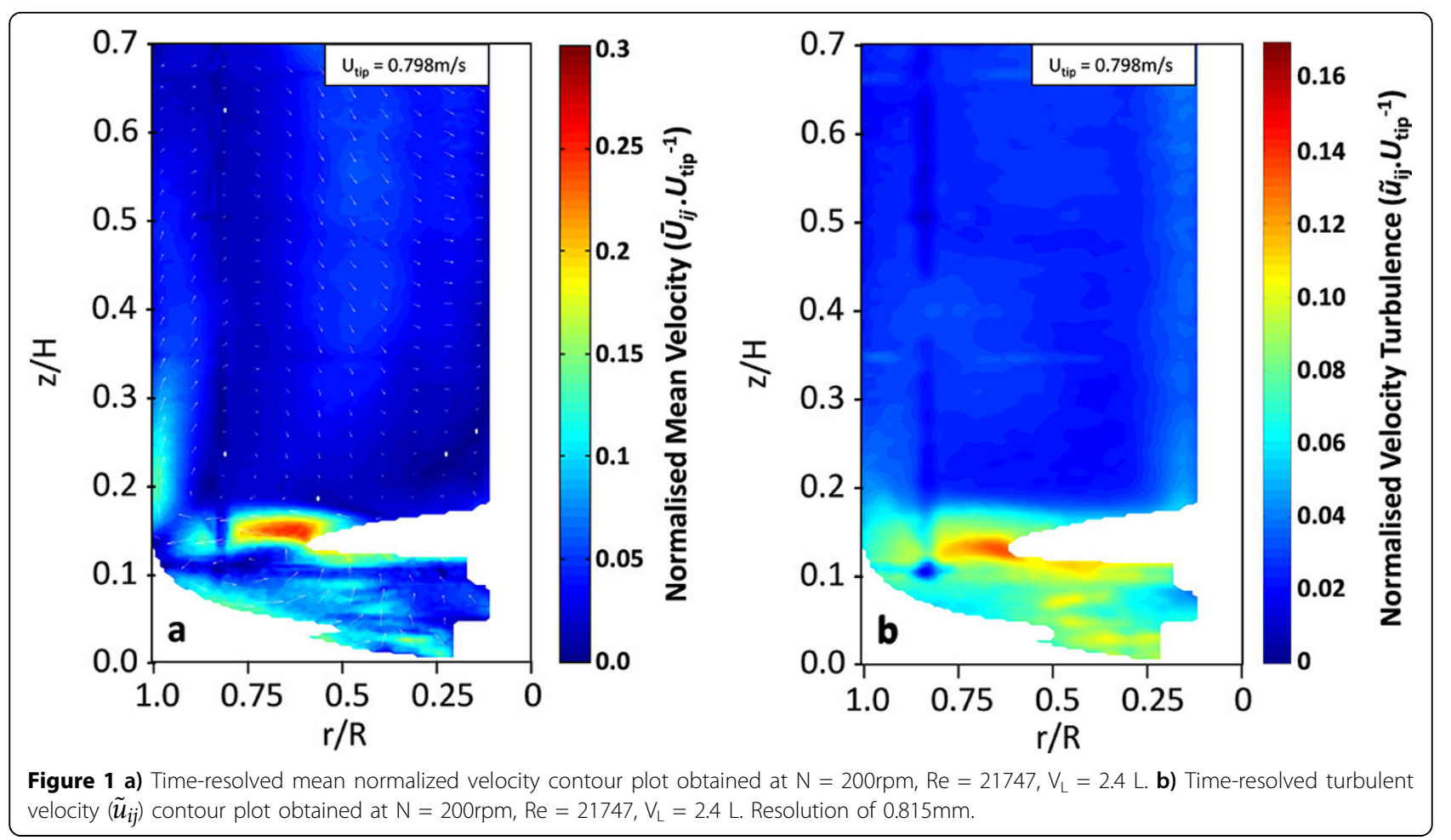

(at approximately $\mathrm{r} / \mathrm{R}=0.65$ and $\mathrm{z} / \mathrm{H}=0.15$ ) as shown in Figure 1, whilst the peak axial and radial turbulent velocities (ũ) are $0.15 \mathrm{U}_{\text {tip }}$ and $0.11 \mathrm{U}_{\text {tip }}$ respectively.

Disparity in cellular growth and viability throughout a range of CellReady operating conditions (80rpm-2.4L, 200rpm-2.4L and 350rpm-1L) was not substantial, although a significant reduction in cell specific productivity was found at $350 \mathrm{rpm}$ and $1 \mathrm{~L}$ working volume. This is considered to be the most stressful hydrodynamic environment tested. Cells grown at these conditions displayed a metabolic shift from lactate production to net lactate consumption, without a reduction in glucose uptake. A possible reason for these observations is increased oxidative stress resulting from the higher agitation rate and gas entrainment $[1,2]$.

The PBS exhibits a greater degree of fluid dynamic homogeneity when compared to the CellReady. Although, TKE is more than 10 times lower than values observed in the CellReady's impeller zone (which ranges from 0.0026 to $0.0455 \mathrm{~m}^{2} / \mathrm{s}^{2}$ at the varying impeller rates tested). Whilst TKE in the PBS peaks at approximately $0.0022 \mathrm{~m}^{2} / \mathrm{m}^{2}$ with a wheel speed of $38 \mathrm{rpm}$, the fluid attains velocities of up to $50 \%$ of the PBS wheel speed. This corresponds to velocities of up to $15 \mathrm{~cm} / \mathrm{s}$, which is within a similar range to the values observed in the CellReady.

The Sartorius RM induces fluid velocities of up to $37 \mathrm{~cm} / \mathrm{s}$ at $25 \mathrm{rpm}$, although fluid velocity and turbulence is dominated by the radial component. EDR and TKE remain relatively low at $25 \mathrm{rpm}$, with mean whole-field ensemble-averaged values of up to $0.0044 \mathrm{~m}^{2} / \mathrm{s}^{3}$ and $0.0020 \mathrm{~m}^{2} / \mathrm{s}^{2}$ respectively. These measurements are significantly lower than the mean EDR values of 0.0052 to $0.14 \mathrm{~m}^{2} / \mathrm{s}^{3}$ (over the $\mathrm{RPM}$ range of $\mathrm{N}=80$ to $350 \mathrm{rpm}$ ) determined in the upper three quarters of the CellReady alone. Cellular response to an increase in turbulence within the rocked bag bioreactor (25 to $42 \mathrm{rpm}$ ), results in an increase in stationary phase viable cell concentration (VCC) of $20 \%$. In addition, cell metabolic activity and cell specific protein productivity remains relatively unchanged. The augmented homogeneity and consistency in reference to turbulence and shear stresses within the Sartorius RM may enable the cells to adapt to the more rigorous mixing, thus maintaining cell specific productivity as well as enhancing VCC. Also, cells grown in the Sartorius RM exhibit more than $60 \%$ greater cell specific productivity levels and up to $37 \%$ greater $\operatorname{IgG}_{4}$ titres compared to those grown in the CellReady. Even though $\operatorname{IgG}_{4}$ productivity increases within the Cultibag, investigations into product quality are necessary.

Given the shifts seen in metabolic behaviour and cell specific productivity, it can be concluded that the fluid dynamic environment will impact upon cellular performance. Clearly, the range of EDRs and TKEs experienced by the culture is just as pertinent as the peak turbulence levels. Therefore, determining the critical hydrodynamic parameters applicable to the different 
flow regimes found in SUBs, will enable greater crosscompatibility and scalability across the range of SUBs.

Published: 4 December 2013

\section{References}

1. Mckenna T: Oxidative stress on mammalian cell cultures during recombinant protein expression. Linkoping University Institute of Technology; 2009, 10.

2. Sengupta N, Rose ST, Morgan J: Metabolic flux analysis of $\mathrm{CHO}$ cell metabolism in the late non-growth phase. Biotechnol Bioeng 2011, 108:82-92.

doi:10.1186/1753-6561-7-S6-P91

Cite this article as: Odeleye et al.: Engineering characterisation of singleuse bioreactor technology for mammalian cell culture applications. BMC Proceedings 2013 7(Suppl 6):P91.

Submit your next manuscript to BioMed Central and take full advantage of:

- Convenient online submission

- Thorough peer review

- No space constraints or color figure charges

- Immediate publication on acceptance

- Inclusion in PubMed, CAS, Scopus and Google Scholar

- Research which is freely available for redistribution

Submit your manuscript at www.biomedcentral.com/submit 